\title{
A novel HIV-1-encoded microRNA enhances its viral replication by targeting the TATA box region
}

\author{
Yijun Zhang ${ }^{1,2}$, Miaomiao Fan ${ }^{1,2}$, Guannan Geng ${ }^{1,2}$, Bingfeng Liu ${ }^{1,2}$, Zhuoqiong Huang ${ }^{1,2}$, Haihua Luo ${ }^{1,2}$, Jie Zhou ${ }^{1,2}$, \\ Xuemin Guo ${ }^{1,2}$, Weiping Cai ${ }^{3}$ and Hui Zhang ${ }^{1,2^{*}}$
}

\begin{abstract}
Background: A lot of microRNAs (miRNAs) derived from viral genomes have been identified. Many of them play various important roles in virus replication and virus-host interaction. Cellular miRNAs have been shown to participate in the regulation of HIV-1 viral replication, while the role of viral-encoded miRNAs in this process is largely unknown.

Results: In this report, through a strategy combining computational prediction and deep sequencing, we identified a novel HIV-1-encoded miRNA, miR-H3. MiR-H3 locates in the mRNA region encoding the active center of reverse transcriptase (RT) and exhibits high sequence conservation among different subtypes of HIV-1 viruses. Overexpression of miR-H3 increases viral production and the mutations in miR-H3 sequence significantly impair the viral replication of wildtype HIV-1 viruses, suggesting that it is a replication-enhancing miRNA. MiR-H3 upregulates HIV-1 RNA transcription and protein expression. A serial deletion assay suggests that miR-H3 targets HIV-1 5' LTR and upregulates the promoter activity. It interacts with the TATA box in HIV-1 5' LTR and sequence-specifically activates the viral transcription. In addition, chemically-synthesized small RNAs targeting HIV-1 TATA box activate HIV-1 production from resting CD4 ${ }^{+} \mathrm{T}$ cells isolated from HIV-1-infected patients on suppressive highly active antiretroviral therapy (HAART).
\end{abstract}

Conclusions: We have identified a novel HIV-1-encoded miRNA which specifically enhances viral production and provide a specific method to activate HIV-1 latency.

Keywords: HIV-1 viruses, Viral miRNA, TATA box, Transcription activation, Viral replication, Latency

\section{Background}

MiRNA represents a class of small RNA ranged from 2124 nts, which plays important regulatory roles in animal, plant, and fungi $[1,2]$. Virus-encoded miRNAs were initially identified from Epstein-Barr viruses [3]. Since then, increasing virus-encoded miRNAs have been identified $[4,5]$. Most of these miRNAs were reported in DNA viruses such as Herpes and Polyoma viruses, but rarely in RNA viruses [5]. Because of the rapid development of deep sequencing technology which is much more sensitive and quantitative than the conventional cDNA clone sequencing method, more RNA virus-derived miRNAs have been discovered especially from HIV-1, WNV and BLV [6-9].

\footnotetext{
* Correspondence: zhangh92@mail.sysu.edu.cn

${ }^{1}$ Institute of Human Virology, Zhongshan School of Medicine, Sun Yat-sen University, Guangzhou, Guangdong 510080, China

${ }^{2}$ Key Laboratory of Tropical Disease Control of Ministry of Education, Zhongshan School of Medicine, Sun Yat-sen University, Guangzhou,

Guangdong 510080, China

Full list of author information is available at the end of the article
}

Most miRNAs repress gene expression through targeting the 3' UTR of mRNA in cytoplasmic RISC for translation repression or mRNA degradation [1,10-12]. It has been revealed that $5^{\prime}$ UTR and exons could also be the targets of miRNAs for translation repression [13,14]. In addition, miRNAs could also enter the nucleus and modulate gene expression at transcriptional level [15-17]. These findings reveal multiple action modes are exploited by miRNAs for gene expression regulation.

MiRNAs play important roles in the interaction between parasites and their hosts. Cellular miRNAs could affect the viral replication, latency and mediate antiviral defense. For example, miR-122 that is enriched in the liver plays a key role in the accumulation of viral RNAs of hepatitis C viruses [18]. A cellular miRNA effectively restricts the accumulation of the retrovirus primate foamy virus type 1 (PFV-1) in human cells [19]. Our group reported that several miRNAs from resting human $\mathrm{CD} 4^{+} \mathrm{T}$ cells repress the translation of viral proteins and contribute to the latency of HIV-1 [20]. Conversely, viral miRNAs 
could facilitate viral infection through reducing the viral antigens or impairing the host antiviral immune response. For instances, SV40 miR-S1 down-modulates the production of the viral $\mathrm{T}$ antigen (TAg), an early protein which is not required during late infection [21]. An EBVencoded miRNA miR-BART5 targets the proapoptotic factor PUMA to promote host cell survival [22]. Furthermore, an hCMV miRNA, miR-UL112-1, was reported to inhibit the expression of the stress-induced ligand MICB and enable hCMV to escape from the immune surveillance by NK cells [23].

It has been reported that human immunodeficiency virus type 1 (HIV-1) also encode several miRNAs and other small RNAs. Bennasser et al. first performed a computational prediction on HIV-1 encoded miRNAs and found five pre-miRNAs candidates [24]. Subsequently, several groups identified HIV-1 encoded miRNAs from the nef or the TAR element [25-28]. Through the new generation sequencing method, a number of HIV-1-encoded small RNAs were discovered, some of which exhibit the features of miRNA or small interfering RNA (siRNA) $[7,29]$.

These HIV-1 derived small RNAs have been shown to modulate the cellular and/or viral gene expression. A nef-derived miRNA-miR-N367 could block HIV-1 Nef expression in vitro [28]. The expression of the TAR derived miRNA could protect the infected cells from apoptosis by down-regulating cellular genes involved in apoptosis $[27,30]$. Since the expression levels of small non-coding RNAs generated from RNA viruses are relatively low, their roles in viral replication remain largely elusive. Here, we initiated our project by searching for new HIV-1-derived miRNA(s) and have identified a surprising new function for a miRNA isolated from the reverse transcriptase sequence.

\section{Results}

\section{Computational prediction of HIV-1-encoded miRNAs}

By experimental methods, the architecture and secondary structure of the entire HIV-1 RNA genome have been clarified [31], which makes the prediction of HIV-1encoded miRNA(s) more accurate. With the online software mireval (http://mimirna.centenary.org.au/mireval/), we predicted nine putative HIV-1-encoded miRNAs including the TAR region-derived miRNA which was reported previously (data not shown) [26]. However, in addition to TAR region-derived miRNA, only the precursor sequence of miR-H3 could form the classic stem-loop structure of miRNA according to the authentic secondary structure of HIV-1 RNA (Figure 1A and Additional file 1: Figure S1). The precursor sequence of miR-H3 is located at the coding sequence of the HIV-1 reverse transcriptase (RT), amino acids (a.a.) 174-191 (Figure 1B). The miR-H3$3 \mathrm{p}$ mature sequence covers the sequence of the RT

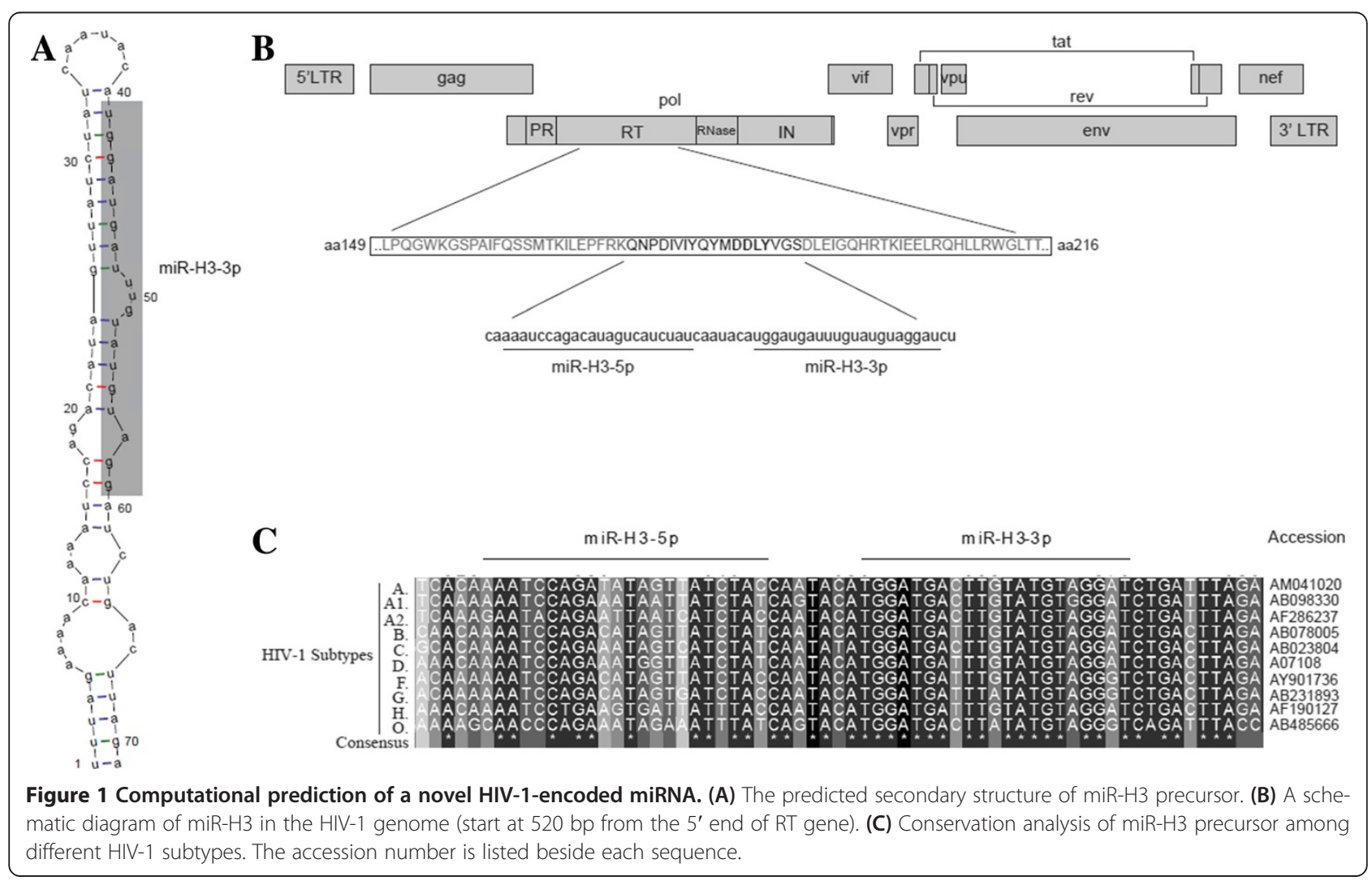


catalytic domain (a.a. DDLY), which is highly conserved among different HIV-1 subtypes (Figure 1C).

\section{Experimental validation of $\mathrm{miR}-\mathrm{H} 3$}

To validate the expression of this miRNA, activated human primary $\mathrm{CD}^{+}$T-lymphocytes were infected with wildtype $\mathrm{HIV}-1_{\mathrm{NL} 4-3}$ viruses. The deep sequencing on small RNAs was conducted with total RNAs isolated from infected or uninfected $\mathrm{CD}^{+}{ }^{+} \mathrm{T}$-lymphocytes. Eighteen and one reads were found to correspond to $3 p$ and $5 \mathrm{p}$ mature sequence of miR-H3 respectively (Figure $2 \mathrm{~A}$ ), which suggests miR-H3-3p (miR-H3 in the following text for convenience) is the guiding strand and miR-H3$5 \mathrm{p}$ is the passenger strand. TAR-derived miRNA has the similar reads in our deep sequencing data as the miRH3-3p (data not illustrated). The expression levels of HIV-1-derived small RNAs are consistent with a recent report [7]. However, miR-H3-3p was not described in the previous studies, which may result from the different programs used for miRNA prediction or different sample preparing methods for deep sequencing $[4,7,29,32]$. To confirm the expression of miR-H3-3p, RNase protection assay (RPA), real-time qRT-PCR and primer extension assay were conducted. In $\mathrm{CD}^{+}$T-cells infected with wildtype $\mathrm{HIV}-1_{\mathrm{NL4-3}}$, a small RNA was specifically detected by RPA with a ${ }^{32} \mathrm{P}$-labeled probe complementary to miR-H3-3p (Figure 2B). The lower band corresponded to the major fraction of the mature miR-H3-3p sequence of $19 \mathrm{nts}$, and the upper band possibly corresponded to the longer slicing products from the miR-H3 precursor, as suggested by the deep sequencing data. These results were also confirmed by real-time qRTPCR assay on the total RNAs from HIV-1 virus-infected primary $\mathrm{CD}^{+} \mathrm{T}$ lymphocytes (Figure $2 \mathrm{C}$ ) and primer extension assay (Additional file 1: Figure S2).

To further reveal whether the generation of miR-H3 is dependent on the miRNA processing pathway, the proteins required for miRNA precursor processing and transport such as Drosha and Exportin-5 were knocked down by siRNAs, and the expression of miR-H3-3p was significantly reduced (Figure 2D). The subcellular distribution analysis of miR-H3-3p suggested that it has equal amount in the nucleus and the cytoplasm, indicating a possible role it plays in the nucleus (Figure 2E).

\section{MiR-H3 enhances viral production and replication}

To investigate the possible effect of miR-H3 on viral replication, we generated a construct containing the precursor of miR-H3 which could express miR-H3 efficiently (Figure 3A). Mutations introduced to the precursor sequence significantly impaired the generation of mature miR-H3-3p (Additional file 1: Figure S3), suggesting the wildtype sequence is important for the proper processing of the precursor. The overexpression of miR-H3 substantially enhanced the virus production when the Env-defective HIV-1 clone, pNL4-3-deltaE-EGFP [33], was transfected into HEK293T cells (Figure 3B). This result was also confirmed with the overexpression of miR-H3 in a cell line named TZM-bl which contains an integrated HIV-1 promoter-driven luciferase gene [34] (Additional file 1: Figure S4). Alternatively, when the precursor sequence of miR-H3 was mutated to disturb its normal secondary structure without changing the corresponding amino acids in pNL4-3-deltaE-EGFP (Additional file 1: Figure S5A), the viral production was reduced (Figure $3 \mathrm{C}$ ). To study the effect of miR-H3 on the replication of wildtype HIV-1 viruses, we introduced the similar silent mutations into the sequence of miR-H3-3p in the wildtype HIV- $1_{\mathrm{NL} 4-3}$ to eliminate its precursor processing (Figure $3 \mathrm{D}$ top, Additional file 1: Figure $\mathrm{S} 5 \mathrm{~B})$. The reverse transcriptase activity assay indicated that the mutations did not impair the activity of reverse transcriptase at different concentrations (Figure 3D bottom). The infectivity experiment of wildtype HIV-1 viruses suggested that the deficiency of miR-H3 substantially reduced the replication of HIV-1 in activated human $\mathrm{CD}_{4}^{+}$ T-lymphocytes (Figure 3E).

\section{MiR-H3 increases viral RNA accumulation}

Since we observed miR-H3 could enhance virus production of the Env-defective HIV-1 clone pNL4-3-deltaEEGFP, whose virus production begins with transcription, we firstly checked whether the transcription of HIV-1 total RNA was manipulated by miR-H3. Overexpression of miR-H3 by the precursor construct upregulated the expression of HIV-1 total RNAs transcribed from pNL43-deltaE-EGFP plasmid (Figure 4A). The HIV-1 total RNA is determined by the RNA transcripts containing the HIV-1 R and U5 sequence [35]. Alternatively, when the miR-H3-encoding sequence was mutated in the pNL4-3-deltaE-EGFP plasmid, there was a significative reduction of $\mathrm{HIV}-1$ total RNAs transcribed from pNL43-deltaE-EGFP (Figure 4B). We next checked whether the HIV-1 protein production had been affected by miRH3. Western blot was performed using an antibody against P24 protein which could also recognize its precursors P55 and P41 in the cytoplasm. The expression of Gag proteins including P55, P41 and P24 were substantially enhanced by miR-H3 (Figure 4C). These results suggested that miR-H3 could facilitate the accumulation of HIV-1 RNAs in the cells. This regulation could be achieved via two ways: one is by enhancing the transcriptional activity of the promoter, and another is by increasing the stability of the RNAs.

\section{MiR-H3 targets HIV-1 5' LTR for promoter activation}

To identify the targeting site of miR-H3 on the HIV-1 genome, different generations of lentiviral vectors, which are derived from the HIV-1 genome with reduced viral 


\section{A NL4-3 3070-3156 t0123388 $\times 3$ t0 $0185018 \times 2$ t0050799 $\times 10$ t0118967×3 t0613914×1}

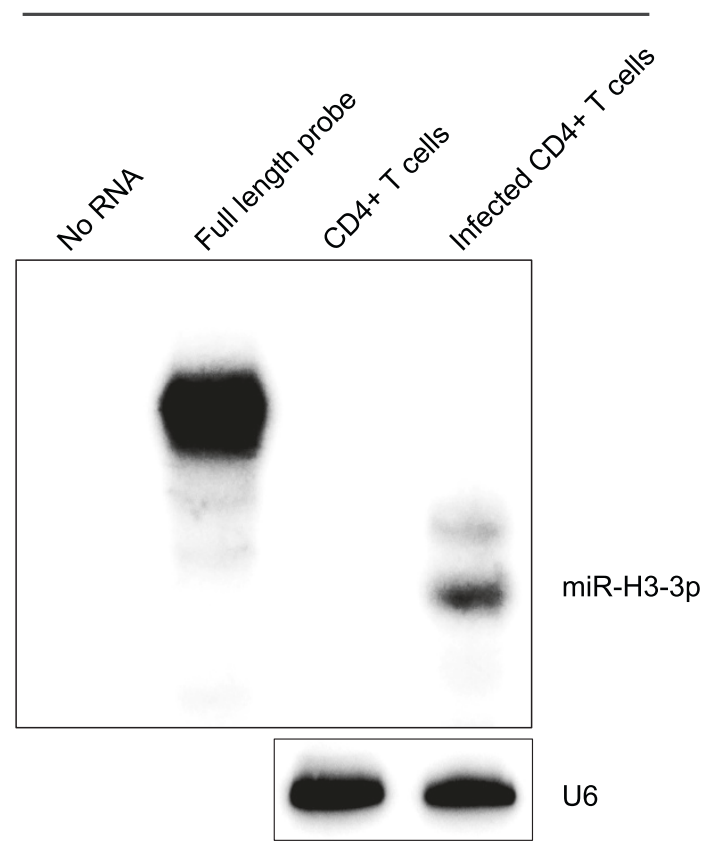

D

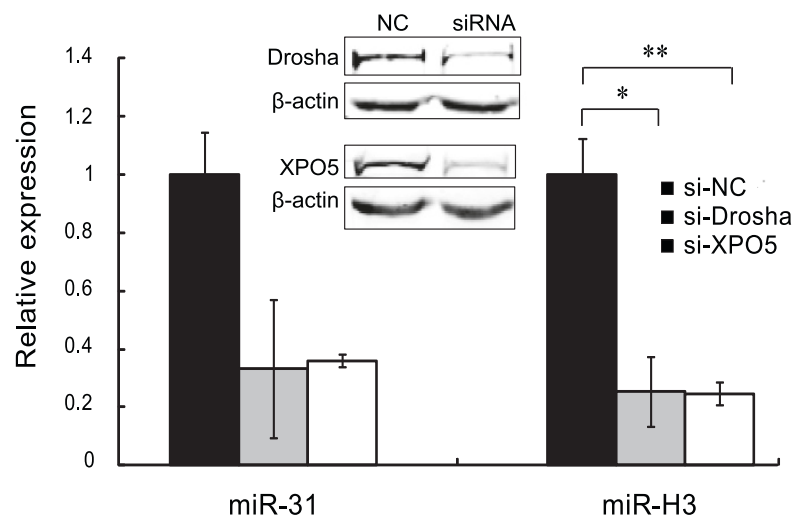

AAAATCTTAGAGCCTTTAGAAACAAATCCAGACATAGTTATCTATCAATACATGGATGATTTGTATGTAGGATCTGACTTAGAAATAGGCAGCATAG

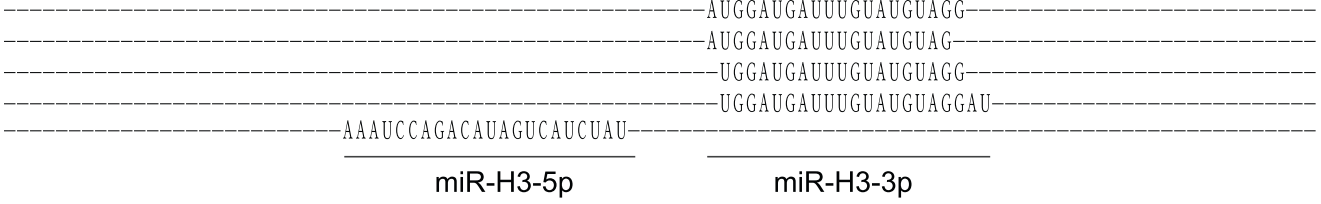

\section{C}

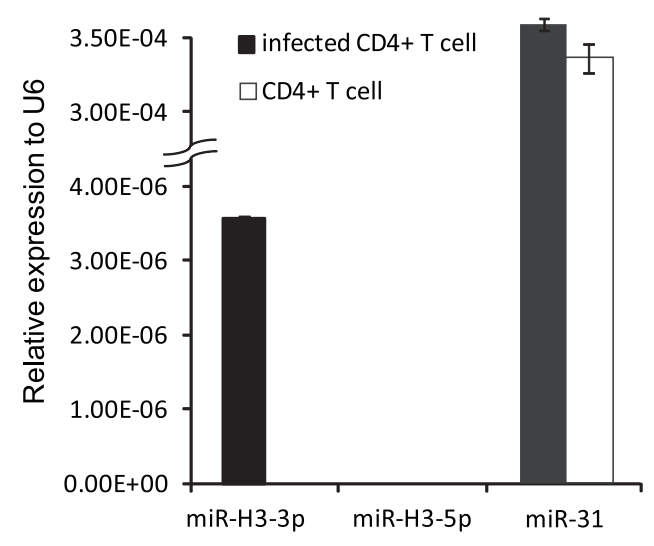

E

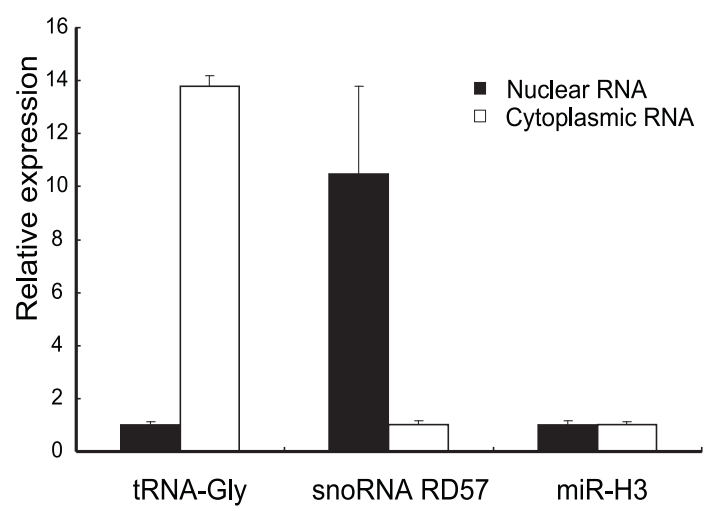

Figure 2 Experimental validation of miR-H3. (A) Mature miRNA sequences revealed by deep sequencing. Primary human CD4 ${ }^{+}$T-lymphocytes isolated from healthy donors were activated with anti-CD3 $(1 \mu \mathrm{g} / \mathrm{ml})$ and anti-CD28(5 $\mu \mathrm{g} / \mathrm{ml})$ antibodies and infected with wildtype HIV-1 $\mathrm{NL}_{4-3}$ Viruses. The total RNAs from infected or uninfected CD4 ${ }^{+}$T-lymphocytes were extracted for deep sequencing on small RNA profiling. (B) RNase protection assay of

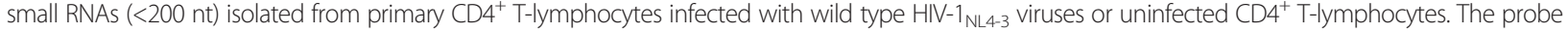
is corresponding to 34-71 nt of the miR-H3 precursor. U6 RNA was detected as the loading control for RPA. (C) Real-time qRT-PCR was conducted on total RNAs isolated from infected or uninfected activated CD4 ${ }^{+}$T-lymphocytes with primers for miR-H3-3p and miR-H3-5p respectively. MiR-31 was set as a positive control, while U6 RNA expression was set as the internal control and set as 1 unit. (D) Two key factors in miRNA processing, DROSHA and XPO5, were knocked-down with siRNAs, and the expression of miR-H3-3p from its precursor transfected into HEK293T was investigated by qRT-PCR as described above. (E) Subcellular localization of miR-H3. HEK293T cells were transfected with pCMV- $\Delta$ R8.2 vector. Fouty-eight hrs later, nuclear and cytoplasmic RNAs were isolated separately and the expression of tRNA-Gly, snoRNA-snoRD57 and miR-H3-3p were tested with real-time qRT-PCR. P-values were calculated using the two tailed unpaired Student's t-test with equal variances, $n=3 .{ }^{*} p<0.05,{ }^{* *} p<0.01,{ }^{* * *} p<0.001$. 


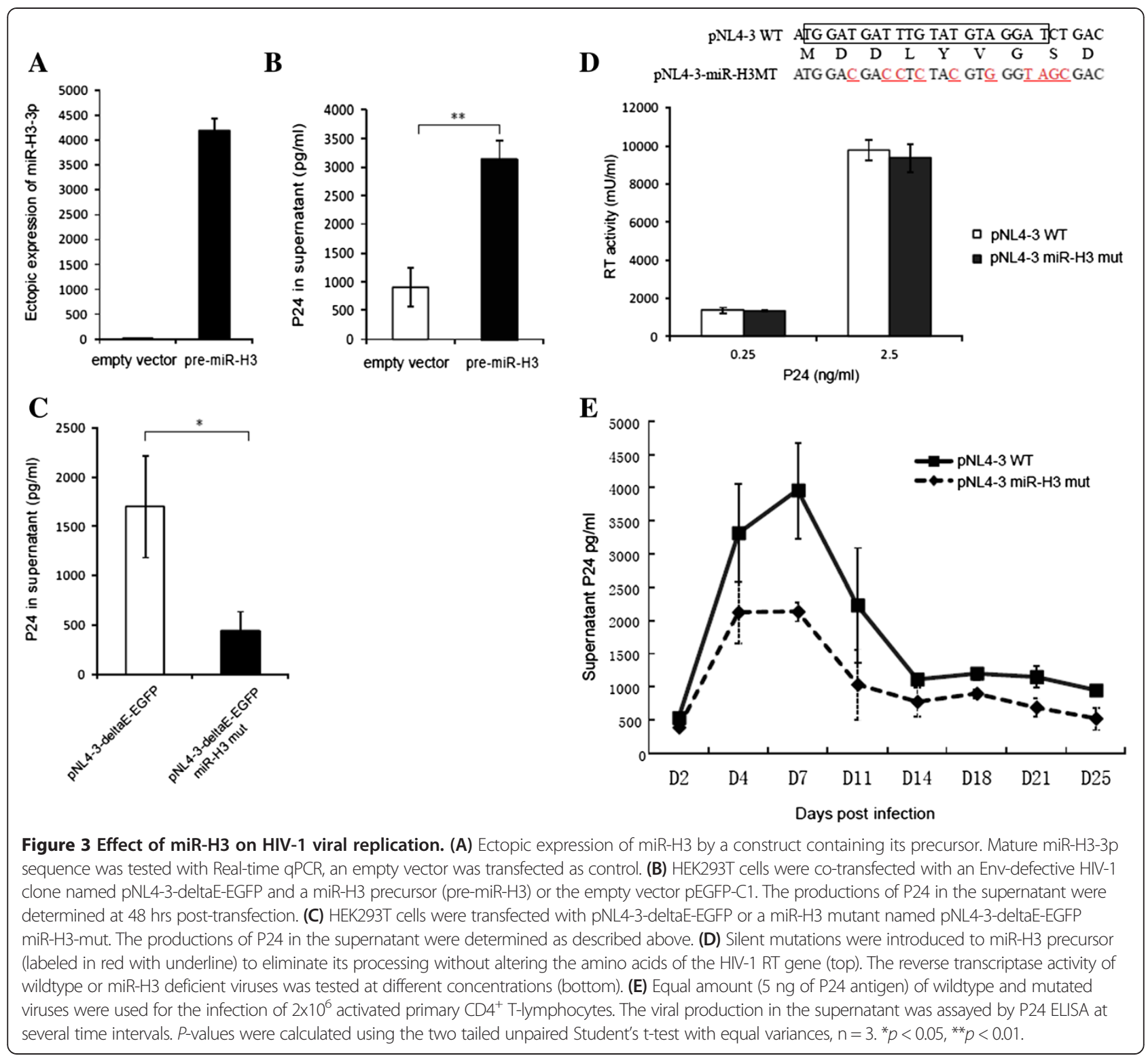

genes and elements, were used to examine the possible direct target of miR-H3. The first is pNL43-deltaE-EGFP vector, which contains the entire HIV-1 genome except for the env gene which was impaired and replaced with a $g f p$ gene. The second is $\mathrm{pCMV}-\triangle \mathrm{R} 8.2$ vector, which contains similar genes with pNL4-3-deltaE-EGFP but lacks of $5^{\prime}$ and $3^{\prime}$ LTR regions. The third is psPAX2 vector, which only contains gag, pol, tat, rev genes and rre motifs (Figure 5A top). When co-transfected these vectors with miR-H3 precursor or the empty vector, we found that miR-H3 could only enhance the RNA expression of pNL4-3-deltaE-EGFP, but not that of the other two vectors (Figure 5A bottom), suggesting its targeting site is located on $5^{\prime}$ or $3^{\prime}$ LTR region. To clarify which region is the target of miR-H3, the LTR regions were cloned into a luciferase reporter plasmid, pMIR- REPORT. The
5' LTR sequence was inserted into the upstream of firefly luciferase gene to replace its CMV promoter, while the 3' LTR sequence was inserted to the 3' UTR region of the firefly luciferase gene with a MMLV (moloney murine leukemia virus) promoter whose activity is similar to that of HIV-1 5'LTR. Ectopic expression of miR-H3 substantially enhanced the luciferase activity of the construct containing HIV-1 5' LTR as the promoter, but not that of the construct containing HIV-1 3' LTR as the 3'-UTR (Figure $5 \mathrm{~B}$ ). These results implied that miR-H3 targets the 5' LTR region of HIV-1 and most probably worked through enhancing the promoter transcriptional activity.

\section{MiR-H3 targets HIV-1 TATA box sequence-specifically}

With computational prediction, we surprisingly found a putative binding site of miR-H3 which covers the core 

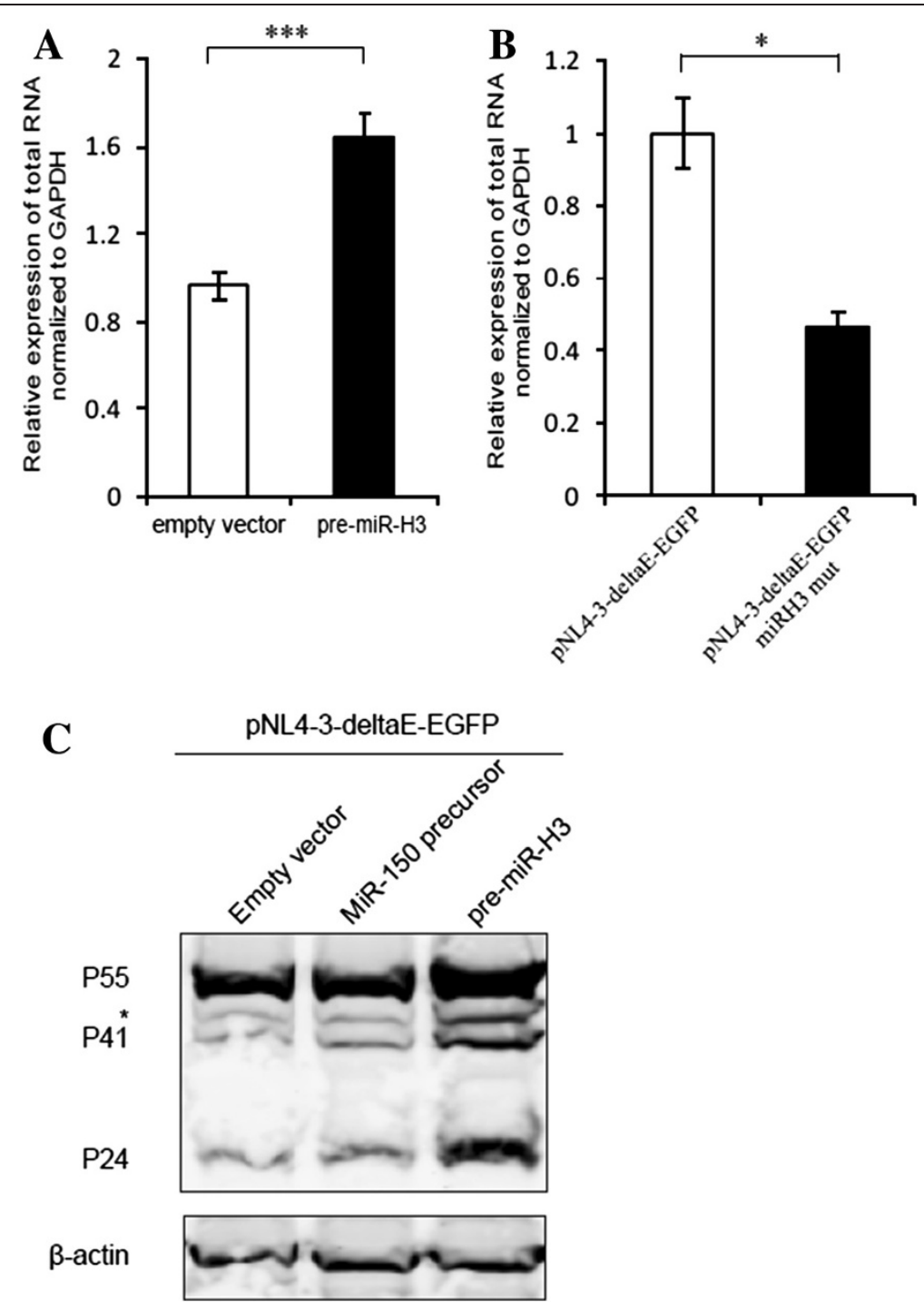

Figure 4 MiR-H3 upregulates HIV-1 total RNA and protein level. (A) Real-time qRT-PCR analysis of HIV-1 total transcripts from HEK293T cells transfected with pNL4-3-deltaE-EGFP and a construct harboring the miR-H3 precursor or the empty vector. (B) pNL4-3-deltaE-EGFP or a miR-H3-defective construct pNL4-3-deltaE-EGFP-miRH3-mut was transfected into HEK293T cells and total HIV-1 transcripts were assayed with real-time qRT-PCR at 48 hrs post-transfection. GAPDH was set as the internal control. (C) Western blot of HIV-1 structural protein P55, P41 and P24 in HEK293T cells transfected with pNL4-3-deltaE-EGFP and the empty vector, the construct containing miR-150 precursor or miR-H3 precursor. The $\beta$-actin was used as an internal control. $P$-values were calculated using the two tailed unpaired Student's t-test with equal variances, $\mathrm{n}=3 .{ }^{*} p<0.05,{ }^{* * *} p<0.001$.

promoter (the TATA box) in HIV-1 5' LTR region (Figure 6A). The TATA box motif in HIV-1 5' LTR starts two nucleotides further upstream and turns to the sequence CATATAA in all subtypes except for subtype $\mathrm{E}$ [36]. When mutations were introduced into the binding site in the TATA box region, the enhancement effect on promoter activity by miR-H3 was impaired (Figure 6B), suggesting that the direct binding between the core promoter and miR-H3 is required for its regulation. Furthermore, we mutated the TATA box region of CMV promoter to the same sequence as that of HIV-1 5' LTR, and found that the transcription of this mutant could also be enhanced by miR-H3 (Figure 6C). These results suggest that the binding site in HIV-1 5' LTR interacts with miR-H3 sequence-specifically and is required for the promoter activation induced by miR-H3. To investigate whether miR-H3 increases the binding of general transcription factors to the HIV-1 core promoter, we carried out ChIP assay with antibody against the RNA Polymerase II or the TATA box binding protein (TBP). The result suggested miR-H3 enhanced the association of both factors to the HIV-1 core promoter region (Figure 6D). As Tat protein is a very important regulatory factor for HIV-1 transcription, we investigated 


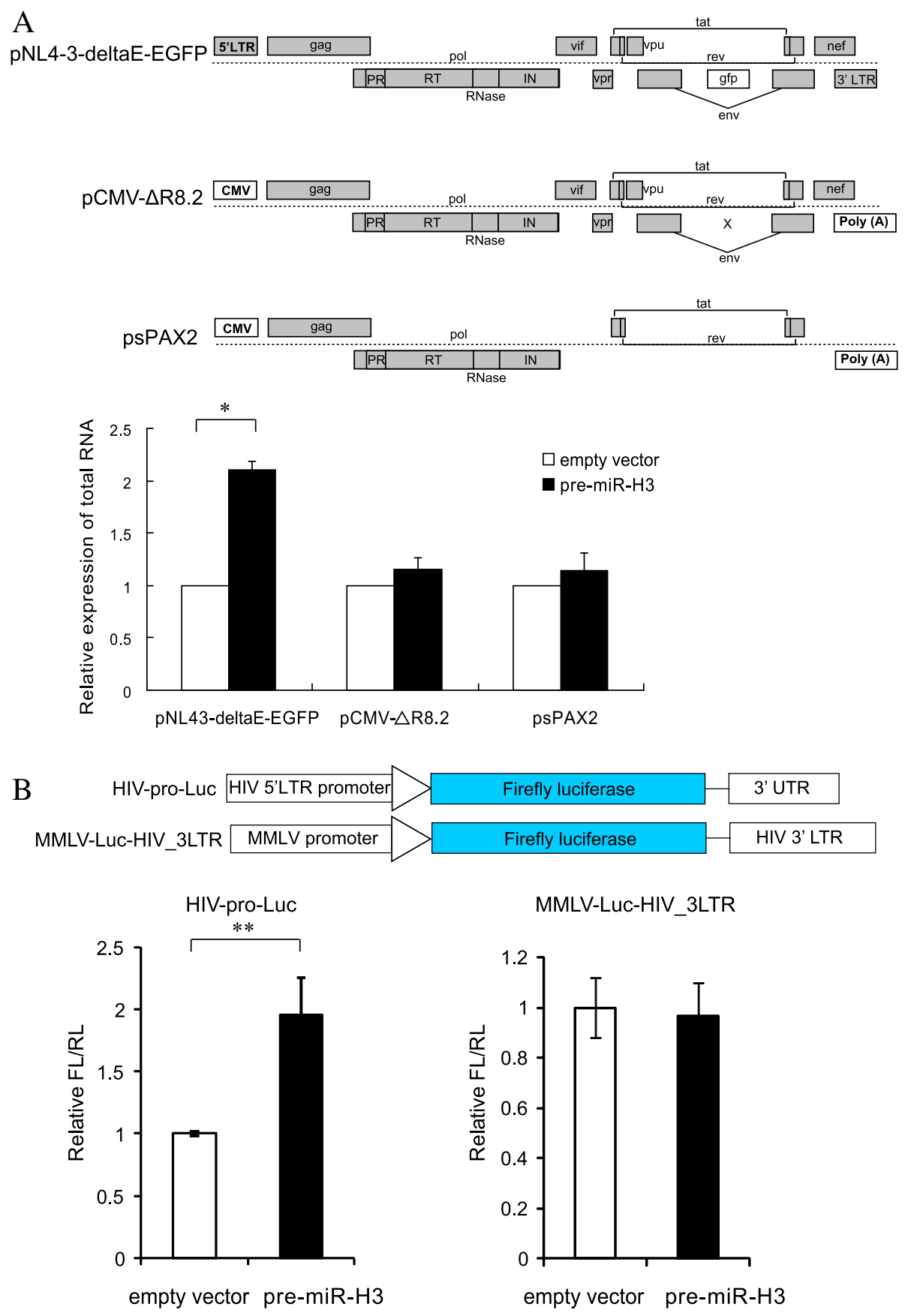

Figure 5 MiR-H3 targets HIV-1 5' LTR and upregulates HIV-1 promoter activity. (A) Effects of miR-H3 overexpression on different HIV-1 derived lentiviral vectors. pNL4-3-deltaE-EGFP, pCMV- $\triangle R 8.2$ and pAX2 are all HIV-1 derived lentiviral vectors with major difference in their $5^{\prime}$ and 3' ends: pNL4-3-deltaE-EGFP contains HIV-1 LTRs, the other two contain most viral protein genes which were driven by a CMV promoter. MiR-H3 precursor was co-transfected with these vectors separately, and then the HIV-1 total transcripts from these plasmids were determined by real-time GRT-PCR. (B) Dual-Luciferase assay was performed on the reporter construct with a HIV-1 5'-LTR functioning as the promoter or a HIV-1 $3^{\prime}$-LTR sequence as the $3^{\prime}$-UTR region after co-transfection with the miR-H3 precursor or the empty vector. $P$-values were calculated using the two tailed unpaired Student's t-test with equal variances, $n=3 .{ }^{*} p<0.05,{ }^{* *} p<0.01$.

whether the interaction between Tat protein and TAR motif affected the HIV-1 promoter activation induced by miR-H3. Our data indicated that, in the absence of Tat, miR-H3 still upregulated HIV-1 promoter activity (Figure 6E). Alternatively, although the deletion of TAR significantly affected the promoter 
C

HIV 5' LTR 5'-ATGCTACATATAAG CAGCTG -3' miR-H3-3p 3'- UAGGAUGUAUGUUAGUAGGU

B hiv 5'ltr 5'-atgcta catataAgcagctg - 3 , HIV 5' LTR mut 5'- ATAACACATATAAGCAGCTG -3 '
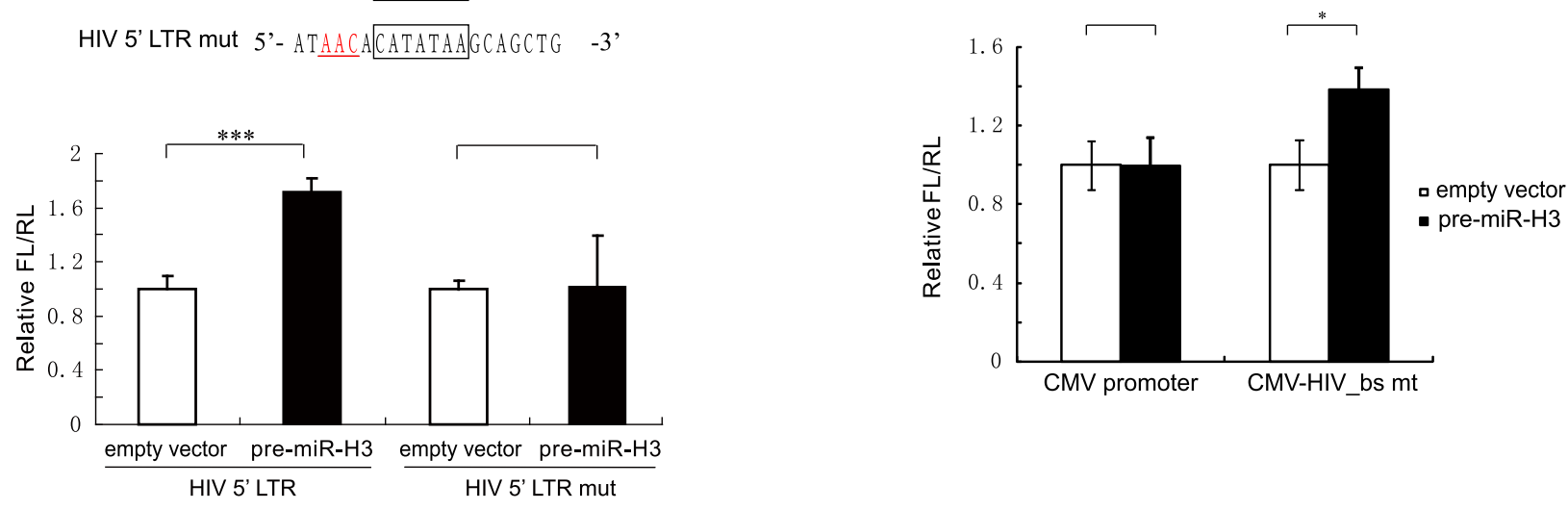

$\mathrm{D}$

Polll ChIP
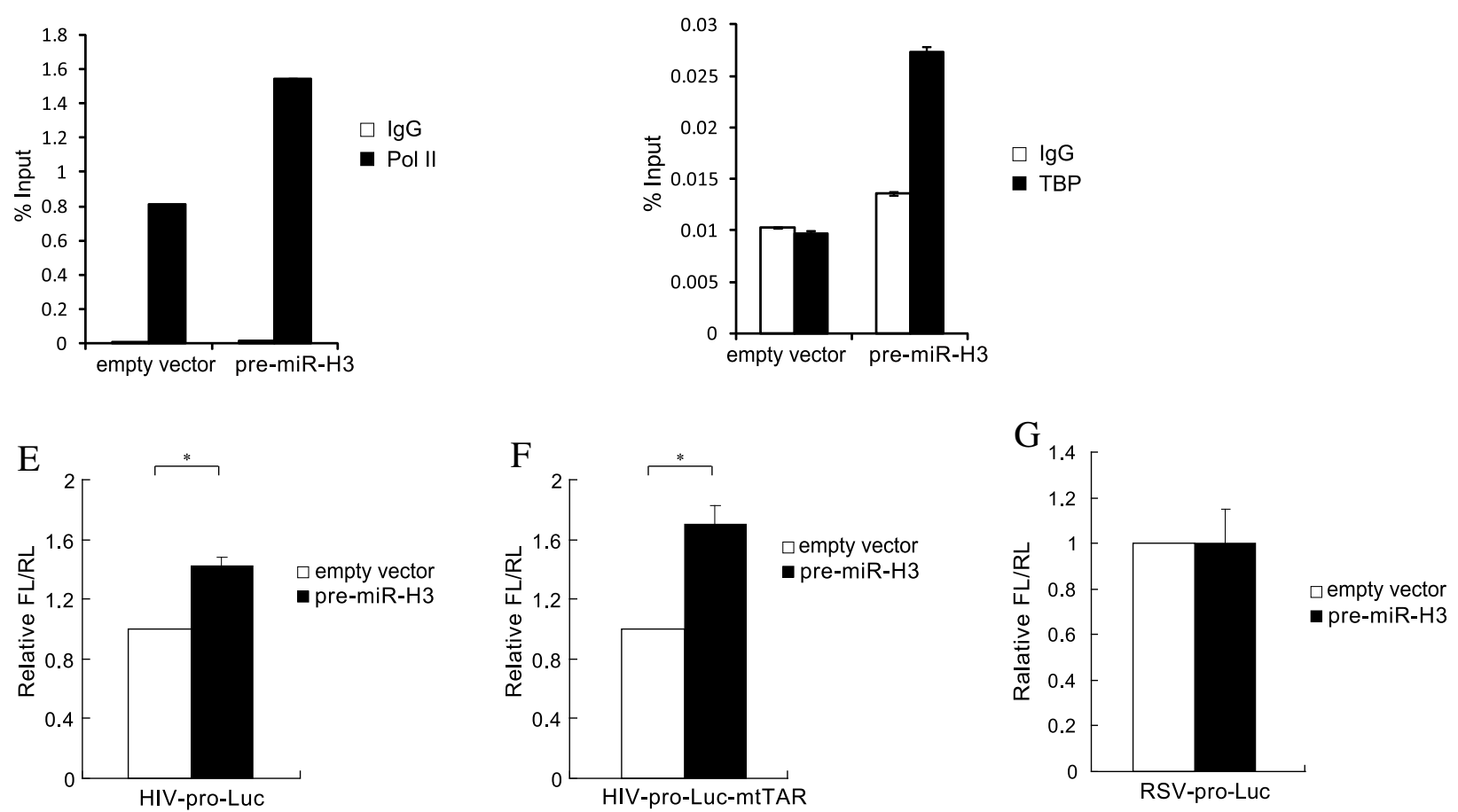

Figure 6 (See legend on next page.)
CMV promoter gGagGGTatacgaggGagGTCTATATAAg CAgAgC

CMV-HIV_bs mt 5'-ATGCTACATATAAG CAGCTG -3'

miR-H3-3p 3'- UAgGaUguaUguUUaguagG $-5^{\text {' }}$
TBP ChIP 
(See figure on previous page.)

Figure 6 MiR-H3 targets the TATA box in HIV-1 5' LTR via sequence specific manner. (A) Predicted binding site of miR-H3 in HIV-1 5' LTR with the TATA box highlighted. The MFE of this interaction is $-19.2 \mathrm{kcal} / \mathrm{mol}$. (B) Mutations (labeled in red with underline) were introduced to the promoter, named HIV 5' LTR mut. The effects of miR-H3 on promoter activity of wildtype or mutated promoter were determined with dual-luciferase assay. The TATA box motif was indicated with a box. (C) Top, the TATA box motif of CMV promoter was replaced by the binding site of miR-H3 on HIV-1 promoter (CMV-HIV_bs mt). The mutated nucleotides are indicated in red with underline. Bottom, the effects of miR-H3 on indicated promoter activities were determined with Dual-Luciferase assay as described above. The TATA box motif was indicated with a box. (D) ChIP assay of HEK239T cells co-transfected with pNL4-3-deltaE-EGFP and pre-miR-H3 or the empty vector with antibody against Pol II or TBP to examine the binding of these general transcription factors to the HIV-1 core promoter region. The normal lgG was used as a control. (E) The effects of miR-H3 on HIV-1 promoter activity without Tat expression. (F) Effect of miR-H3 on the activity of a TAR region deficient (deletion of 470 to 492 bp in HIV-1 5' LTR) HIV-1 promoter. (G) The effect of miR-H3 on another retrovirus promoter. A RSV promoter-derived luciferase reporter construct was co-transfected with miR-H3 precursor or control vector, and the promoter activity was investigated by Dual-Luciferase assay.

$P$-values were calculated using the two tailed unpaired Student's t-test with equal variances, $n=3 .{ }^{*} p<0.05,{ }^{* * *} p<0.001$.

activity, the enhancement activity by miR-H3 was not affected (Figure 6F). Furthermore, miR-H3 did not affect the promoter activities of another retrovirus, Rous sarcoma virus (RSV), arguing against a nonspecific transcription regulation on retroviruses (Figure 6G).

\section{The small RNAs targeting HIV-1 TATA box activate viral production from latently infected resting $\mathrm{CD}^{+} \mathrm{T}$ cells}

HIV-1 latency in resting primary $\mathrm{CD}^{+} \mathrm{T}$ cells is the major barrier for the eradication of the viruses in HIV1 -infected patients on suppressive HAART. As miR-H3 has the enhancement activity on HIV-1 promoter, it is interesting to examine whether TATA-targeting miRNA/ siRNA could be used to activate HIV-1 latency. To this end, we synthesized various small RNAs including miRNA mimics and siRNAs complementary to HIV-1 TATA box sequence. Among them, si-HIV-TATA-msig contains three nucleotides of mismatch in its $5^{\prime}$ end to avoid a possible RNA interference effects caused by the attachment of the small RNA to the 3' LTR of HIV-1 mRNA (Figure 7A). We found that some siRNAs enhanced the promoter activity more efficiently than the synthesized miRNA mimics in HEK293T cells (with the HIV-pro-Luc plasmid, data not shown). When cotransfected with the Env-defective HIV-1 clone pNL4-3deltaE-EGFP, siRNAs against HIV-1 TATA box potently increased the P24 antigen production with more stable performances (Figure 7B). Finally, we examined the effect of these small RNAs upon HIV-1 latency in resting $\mathrm{CD}_{4}^{+}$ $\mathrm{T}$ cells directly isolated from HIV-1-infected individuals receiving suppressive HAART. Post-integration HIV-1 latency in these cells was confirmed by the detection of integrated HIV-1 proviruses in the chromosomal DNA via Alu-PCR (Additional file 1: Figure S6). Stimulation with anti-CD3/anti-CD28 induced the production of a large number of viral particles (Additional file 1: Figure S7). These data suggest that the primary resting $\mathrm{CD}_{4}^{+}$ T-lymphocytes isolated from the patients were latently infected. After transfection with the siRNAs complementary to HIV-1-TATA box, these resting $\mathrm{CD}^{+}{ }^{+} \mathrm{T}$ cells generated significantly more HIV-1 particles than those treated with a negative control siRNA (Figure 7C). This data indicated that a siRNA complementary to HIV-1 TATA box alone is able to activate $\mathrm{HIV}-1$ transcription in the latentlyinfected resting $\mathrm{CD} 4^{+}$T-lymphocytes.

\section{Discussion}

In this report, we found that a novel HIV-1-encoded miRNA could upregulate its viral transcription by targeting the TATA box in the $5^{\prime}$ LTR. Several studies have revealed that small non-coding RNAs (e.g. miRNA and siRNA) target to gene promoters are able to induce gene transcription activation or silence. For instance, miR-373 can activate the expression of E-cadherin and cold-shock domain-containing protein C2 (CSDC2) through a target site in their promoters [15]. Another miRNA, miR-423$5 \mathrm{p}$, induces transcriptional silencing by targeting a highly conserved region in the promoter of progesterone receptor (PR) gene [16]. At the same time, the potential of synthetic small RNAs to manipulate gene transcription was also explored. Morris and coworkers initially reported the inhibition of the EF1 $\alpha$ promoter with a siRNA targeting approximately $100 \mathrm{bp}$ upstream the EF1 $\alpha$ transcription start site (TSS) [37]. Several studies subsequently reported that small RNAs could also induce transcriptional gene activation by targeting gene promoters $[38,39]$. These reports indicate the existence of a small RNA guided transcription regulation mechanism in the nucleus of mammalian cells. For the first time, our study revealed that viruses have exploited this host mechanism to regulate viral replication by virus-encoded miRNAs. However, the targeting sites of miRNA or siRNA on gene promoter in previous studies distribute in a wide range $(\sim 1000 \mathrm{bp}$ upstream of the TSS). In this study, miR-H3 targets the key position for transcription initiation -TATA box, wherein the polymerase II pre-initiation complexes (PICs) are assembled. This finding raises the possibility that miRNAs directly 


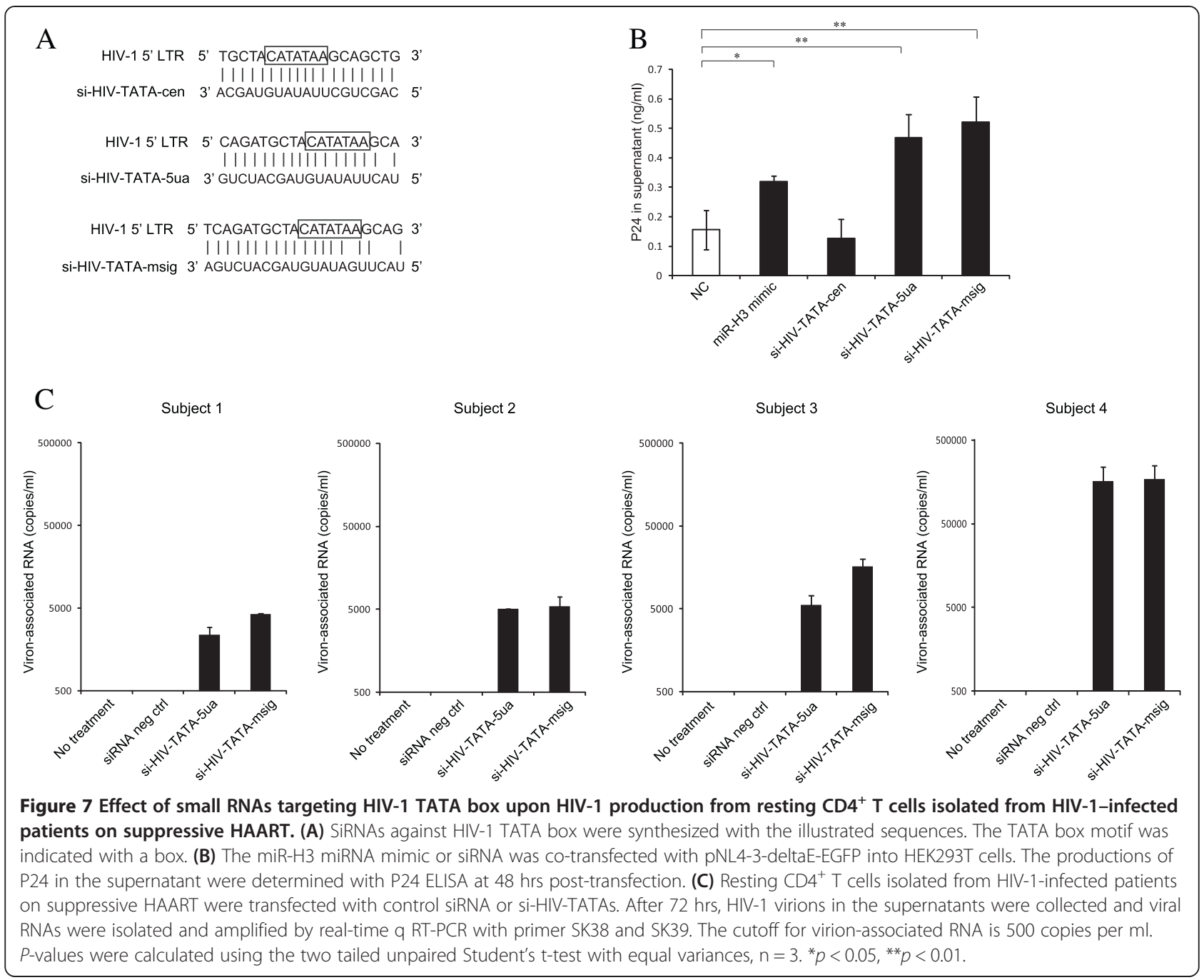

participate in the transcription initiation regulation in mammalian cells.

The transcription activity of HIV-1 provirus is finely modulated in different host cells, which is accomplished through a lot of cellular transcription factors and viral proteins. Cellular transcription factors such as Sp1, NF- $k B$, NF-AT, LEF-1/TCF- $1 \alpha$, C/EBP, and CREB are important for the activation of HIV-1 LTR-driven transcription [40-49]; Conversely, cellular factors including LBP-1, TDP-43, YY1 and P53 exhibit inhibitory effects on LTR-driven transcription [50-54]. It is noteworthy that the effects of many cellular factors are cell-type dependent and there are complicated interaction among these factors (more discussion see the review of Rohr et al. [55]). A key viral regulator of HIV-1 transcription activity is the regulatory protein-Tat, which is produced during early phase of infection and binds to the transactivation-responsive region (TAR) located at the 5 '-end of viral mRNAs [56]. After binding, Tat recruits a diverse series of transcriptional complexes to the viral promoter plexes include enzymes with histone and factor acetyl transferase (HAT and FAT respectively) activities, which modify chromatin conformation at the proviral integration site [58], and a protein complex (P-TEFb) that hyperphosphorylates the carboxy-terminal domain (CTD) of RNA polymerase II, thus promoting the initiation and elongation of viral transcription $[59,60]$. Vpr and Nef also have effects on HIV-1 transcription, which through the interaction with Tat or up-regulating the expression of activating factors such as NF-AT, NF- $\mathrm{kB}$, and AP-1 [61-64]. In this study, we showed that miR-H3 is another HIV-1encoded cis- regulatory element, in addition to Tat, that direct interacts with viral element and regulates transcription activity. It is interesting to investigate whether the effect of miR-H3 is cell-type dependent and identify its cellular co-factors. Our findings further reveal the complexity of transcription regulation for HIV-1.

The advances in next-generation sequencing technology have greatly fueled the discovery of small RNAs, and activates transcription activity [57]. These com- 
especially the low expressed miRNAs. However, their functions are largely unexploited. One opinion about these low expressed miRNAs is that they may not have function due to the low expression levels. This idea is reasonable according to the well-known paradigm that miRNAs function in cytoplasm through targeting the 3' UTR of mRNA for translation repression. This model requires a considerable amount of miRNAs for their functions since their targets are relatively highly expressed. But our data suggest miR-H3 and many cellular miRNAs target the core promoter of HIV-1 virus and many important genes (unpublished data), which are on the chromosomal DNA with very limited copy number in the nucleus in contrast to the massive mRNA molecules in the cytoplasm. Thus the requirement of the accumulation level of these TATA box targeting miRNAs is relatively low. Our data and previous studies on promoter targeting miRNAs probably provide a novel function model for the low expressed miRNAs.

Latent infection of HIV-1 is the major barrier for the eradication of the viruses in patients on suppressive HAART. The first step to remove latent viral reservoirs is reactivating the latent proviruses. Several approaches have been developed to activate latent virus transcription including activating $\mathrm{T}$ lymphocytes with IL-2 or IL-2 plus anti-CD3/anti-CD28 antibody $[65,66]$, protein kinase $\mathrm{C}$ (PKC) activators (e.g. prostatin [67]), and activating transcription with small molecule inhibitors of histone deacetylases without inducing host cell activation (such as, valproic acid (VPA), suberoylanilide hydroxamic acid (SAHA))[68-70]. However, the first approach has been shown to cause serious toxic effects, and the latters are speculated about causing global gene expression activation with unpredictable side effects. Thus, a HIV-1 provirus specific activating reagent is ideal for purging the latent reservoir. In this study, we demonstrated a HIV-1 encoded miRNA could activate HIV-1 transcription in a sequence-specific manner, and the synthesized small RNA induced viral production from resting $\mathrm{CD}^{+}{ }^{+} \mathrm{T}$ cells from patients receiving suppressive HAART treatment. Together with our previous finding that some cellular miRNAs have contributed to the latency of HIV-1[20], a combination of the small RNA(s) targeting to HIV-1 TATA box and the inhibitors of these cellular miRNAs will provide a HIV-1 specific approach for eradicating HIV-1 latent reservoir more safely.

\section{Conclusions}

In this study, we identified a novel HIV-1-encoded miRNA miR-H3, which potently enhances viral production. Unlike most miRNAs that target the 3' UTR of mRNA for translation repression, miR-H3 targets the TATA box in HIV-1 5' LTR to upregulate the promoter activity. It represents another HIV-1-encoded element, in addition to Tat, that activates viral transcription via cis regulation. These findings reveal a new layer of HIV1 replication regulation and may serve as the basis for an innovative approach to specifically activate latent infected HIV-1 viruses.

\section{Methods}

\section{Ethics statement}

This research was approved by the Ethics Review Board of The Eighth People's Hospital at Guangzhou (Guangzhou Infectious Disease Hospital, Guangzhou, China) and the Ethics Review Board of Sun Yat-Sen University. HIV-1infected patients were recruited at The Eighth People's Hospital at Guangzhou and given written informed consent with approval of the Ethics Committees. Deidentified human peripheral blood mononuclear cells (PBMCs) from healthy blood donors were obtained from local volunteers. We did not have any interaction with these human subjects or protected information, and therefore no informed consent was required.

\section{MiRNA in silico prediction}

The genomic sequence of pNL4-3 was downloaded from NCBI and submitted to web server of mireval (http:// mimirna.centenary.org.au/mireval/). A total of 9 miRNA candidates including two associated with TAR regions were suggested. These candidates were further filtered by comparing their secondary structure with that of HIV-1 genomic RNA [31] and coincident ones were chosen for experimental validation. The miRNA precursor structure prediction was performed with the Mfold webserver [71]. Representative sequences of major HIV-1 subtypes were downloaded from the HIV sequence database (http://www.hiv.lanl.gov/content/sequence/HIV/mainpage. html). Alignment of these sequences was performed with Clustal X program. The miRNA binding sites on HIV-1 were predicted with RNA-hybrid web server (http://bibiserv.techfak.uni-bielefeld.de/rnahybrid).

\section{Cell culture}

Sup-T1 and HEK293T cells were obtained from ATCC (American Type Culture Collection, Manassas, VA) and cultured according to ATCC recommendations. TZM-bl cells were obtained from the AIDS Research and Reference Reagent Program, NIAID, US NIH. Human PBMCs were isolated from the whole blood of healthy donors by Ficoll-Hypaque Solution (HAO YANG, Tianjin, China). The resting primary $\mathrm{CD}^{+} \mathrm{T}$ lymphocytes were then isolated from PBMCs with CD4 ${ }^{+} \mathrm{T}$ Cell Isolation Kit II (BD). Human primary PBMCs and $\mathrm{CD}^{+} \mathrm{T}$ cells were grown in the RPMI 1640 conditioned media supplemented with $10 \%$ fetal bovine serum (FBS), $50 \mathrm{U} / \mathrm{ml}$ penicillin and $50 \mu \mathrm{g} / \mathrm{ml}$ streptomycin. 


\section{Plasmids, siRNAs and antibodies}

The infectious HIV-1 clone (pNL4-3) and Env-defective HIV-1 clone (pNL4-3-deltaE-EGFP) were obtained through the AIDS Research and Reference Reagent Program, NIAID, US NIH. The precursor of miR-H3 and hsa-miR150 were amplified by PCR and directionally cloned into the downstream of the EGFP gene in the PEGFP-C1 vector (BD Biosciences). The pNL4-3-miR-H3MT plasmid was constructed by introducing mutations in the region for miR-H3-3p mature miRNA without changing amino acid code. Similar mutations were also introduced into noninfectious HIV-1 clone, pNL4-3-deltaE-EGFP. HIV-pro-Luc plasmid was constructed by replacing the promoter of Luciferase gene in the pMIR-REPORT Luciferase vector (Invitrogen) with HIV-1 5' LTR sequence. MMLV-LucHIV_3LTR plasmid was constructed by replacing the promoter of Luciferase gene in the PMIR-REPORT vector with the MMLV promoter and inserting the HIV-1 3' LTR downstream the luciferase gene. Several mutations were introduced into miR-H3 binding site in the $5^{\prime}$ LTR sequence. HIV-pro-Luc-mtTAR plasmid was constructed with deleting $5^{\prime}$ half region of TAR motif (470 bp to $492 \mathrm{bp}$ region in HIV-1 5' LTR) to abolish its functional secondary structure. RSV-pro-Luc plasmid was constructed by replacing the promoter of Luciferase gene in the pMIR-REPORT vector with the RSV promoter. All the constructs were verified by sequencing. The siRNAs against Drosha and Exportin5 genes were purchased from Dharmacon. Anti- $\beta$-actin antibody (D6A8) was purchased from CST (Danvers, MA). Anti-human CD3 and anti-human CD28 antibodies were from BD (Palo Alto, CA). The rabbit anti-P24 antibody was prepared by our lab.

\section{Infection and transfection}

Infectious HIV-1 clone pNL4-3 was transfected into 60\% confluent HEK293T cells (100 mm plate) using Lipofectamine 2000 according to the manufacturer's protocol (Invitrogen). Viral supernatant was collected 2 days after transfection and viral production was determined by P24 ELISA kit. Five ng P24 $\mathrm{f}$ infectious HIV-1 viruses were used to infect $2 \times 10^{6}$ activated human $\mathrm{CD}^{+} \mathrm{T}$ lymphocytes for $3 \mathrm{hrs}$ at $37^{\circ} \mathrm{C}$. The cells were then washed three times with cold PBS and add fresh conditioned medium containing IL$2(10 \mathrm{ng} / \mathrm{ml})$. Supernatants of cell culture were collected in 2-3 days interval and subject to P24 ELISA detection. Transfection of HEK293T and TZM-bl cells was performed with Lipofectamine 2000 (Invitrogen) according to the manufacturer's protocol. Transfection of primary $\mathrm{CD} 4^{+}$ cells with small RNA was performed with RNAiMAX (Invitrogen) according to the manufacturer's protocol.

\section{Quantitative real-time RT-PCR analysis}

Total RNA from HEK293T or CD4 ${ }^{+} \mathrm{T}$ cells was isolated with Trizol reagent (Invitrogen) and then subjected to cDNA synthesis using PrimeScript RT reagent Kit (Takara). All primers were annealed at $37^{\circ} \mathrm{C}$ and $\mathrm{RT}$ was processed at $42^{\circ} \mathrm{C}$. Quantitative PCR was performed with SYBR Premix ExTaq II Kit (Takara) by following the manufacturer's instructions. The expressions of HIV-1 total RNAs were determined with the primer pair HIVTotRNA-5 F/R. The HIV-1 RT activity assay was performed by following the method described in Vermeire et al. [72]. An in vitro-synthesized HIV-1 RNA, after quantification [73], was used as the external control for measuring virion-associated viral RNA. Quantification was normalized to the housekeeping gene U6 or $\beta$-actin. All primers for HIV-1 gene detection were listed in the additional files. The relative expression levels were calculated using the following equation: $A=2^{[C t(\mathrm{ref})-C t(\text { ref }- \text { control })]}-$ [Ct(sample) - $C t$ (sample - control)] .

\section{Dual-luciferase reporter assay}

HEK293T cells were seeded in 48-well plates (Corning) at a density of 20,000 cells per well one day before transfection. One to $5 \mathrm{ng}$ of HIV-1 wildtype or mutated promoter driven-firefly luciferase (FL) reporter and $2 \mathrm{ng}$ renilla luciferase (RL) constructs were co-transfected with miRNA precursor/mock control into HEK293T cells using Lipofectamine 2000 (Invitrogen) by following the manufacturer's protocol. After 24-48 hrs, FL and RL activities were measured with the Dual-Glo luciferase assay system according to the manufacturer's instructions (Promega).

\section{Protein analysis}

Infectious or defective viral particle production in cell cultures was determined with P24 ELISA kit by following the manufacturer's protocol. Western blotting was carried out as described previously with some minor modifications [74]. The anti-P24 or anti- $\beta$-actin antibodies were used to detect HIV-1 P55, P41 and P24 or $\beta$-actin protein respectively.

\section{RNase protection assay (RPA)}

The activated $\mathrm{CD} 4^{+}$T-cells were infected with viruses produced from HIV-1 clone pNL4-3 or mock infected. At 48 hrs post infection, the fresh $\mathrm{CD} 4^{+} \mathrm{T}$-cells from the same donor were co-cultured with the infected $\mathrm{CD} 4^{+} \mathrm{T}$ cells with a ratio of 3:1 for another $72 \mathrm{hrs}$. Then the total RNAs were isolated with Trizol Reagent (Invitrogen) and the small RNAs $(<200 \mathrm{nt})$ were enriched by using the mirVana miRNA isolation kit (Ambion). The procedure of RPA described by Gilman was followed with some minor modifications [75]. The RNA probe was a sequence complementary to nt 34/71 of miR-H3 precursor and was synthesized from DNA templates by in vitro transcription using the T7 RNA polymerase (NEB) and radiolabeled by random incorporation of $\alpha_{-}{ }^{32}$ P UTP 
(Perkin Elmer). The radiolabeled probe was hybridized with 10 ug of small RNA overnight at $45^{\circ} \mathrm{C}$. After the hybridized RNAs were then treated with RNases A/T1, the protected RNAs were separated by denaturing PAGE $(12 \%)$ and visualized by autoradiography.

\section{Chromatin immunoprecipitation (ChIP) assay}

ChIP assay was performed with Magna ChIP ${ }^{\mathrm{ma}} \mathrm{A} / \mathrm{G}$ Kit (Millipore) by following the manufacture's instruction. Briefly, HEK293T cells were co-transfected with pNL43-deltaE-EGFP and pre-miR-H3 or the empty vector. At 48 hrs post transfection, the cells were collected to carry out ChIP assay with anti-Pol II (8WG16, Covance), TBP (Abcam), or normal IgG antibodies. The HIV-1 promoter sequence corresponding to $-50-(+) 50$ bp relative to the TSS was detected with qPCR.

\section{Additional file}

Additional file 1: Figure S1. The genuine secondary structure of miR-H3 precursor corresponding sequence in HIV-1 genome by Watts et al [31]. Figure S2. Primer extension assay of miR-H3-3p. Total RNAs were isolated from HEK293T cells transfected with a lentiviral vector pCMV- $\Delta R 8.2$ which contains the miR-H3 precursor or a control plasmid for 48 hrs. A small RNA band was detected only in the lane of $\mathrm{pCMV}-\Delta R 8.2$ transfection by a probe specific to miR-H3-3p sequence. Figure S3. Ectopic expression of miR-H3 by constructs containing its wildtype or mutated precursors. Top, the mutated nucleotides were indicated in red; bottom, mature miR-H3-3p sequence was tested with real-time GPCR and normalized to U6. The empty vector was transfected as a control. Figure S4. The effect of miR-H3 on integrated HIV-1 reporter system. TZM-bl cells, containing an integrated HIV-1 promoter-driven luciferase cassette in chromosomal DNA, were transfected with the construct harboring miR-H3 precursor or an empty vector. The transcription activities of HIV-1 promoter were examined by luciferase assay. Figure S5. MiR-H3-3p processed from mutated pNL4-3-deltaE-EGFP (A) or pNL4-3 constructs (B). The plasmid were transfected into HEK293T cells, 48 hrs later total RNAs were isolated and miR-H3-3p expression was determined with qRT-PCR and normalized to U6. Figure S6. Confirmation of integrated HIV-1 proviruses in the chromosomal DNA from resting $\mathrm{CD}^{+} \mathrm{T}$ cells isolated from HIV-1infected patients on suppressive HAART using Alu-PCR. Figure S7. The virus production was induced from resting $\mathrm{CD}^{+} \mathrm{T}$ cells isolated from HIV-1-infected patients on suppressive HAART by anit-CD3/anti-CD28. The viral production in the supernatant was measured by HIV-1 P24 ELISA.

\section{Competing interests}

The authors declare that they have no competing interests.

\section{Authors' contributions}

YZ conducted the most experiments and performed the analyses. YZ, MF, and $\mathrm{HZ}$ wrote the manuscript. $\mathrm{YZ}$ and $\mathrm{HZ}$ conceived the study and contributed to data interpretation, and $\mathrm{HZ}$ supervised the project. MF, GG, $\mathrm{BL}, \mathrm{ZH}, \mathrm{HL}$ performed some experiments. JZ, XG and WC contributed to collect the clinical samples. All authors read and approved the final manuscript.

\section{Acknowledgments}

This work was funded in part by the National Special Research Program for Important Infectious Diseases (No.2013ZX10001004), National Basic Research Program of China (973 Program) (No.2010CB912202), Guangdong Innovative Research Team Program (No.2009010058), National Natural Science Foundation of China (No.30972620). Natural Science Foundation of Guangdong (No.9251008901000022), Research Fund for the Doctoral
Program of Higher Education of China (No.20090171110083) to H.Z. National Natural Science Foundation of China (No. 81301431), China Postdoctoral Science Foundation (No. 2012 M511866 and No. 2013 T60824) to Y.J.Z.

\section{Author details}

Institute of Human Virology, Zhongshan School of Medicine, Sun Yat-sen University, Guangzhou, Guangdong 510080, China. ${ }^{2}$ Key Laboratory of Tropical Disease Control of Ministry of Education, Zhongshan School of Medicine, Sun Yat-sen University, Guangzhou, Guangdong 510080, China. ${ }^{3}$ Department of Infectious Diseases, Guangzhou Eighth People's Hospital, Guangzhou Medical University, Guangzhou, Guangdong 510080, China.

Received: 1 November 2013 Accepted: 18 February 2014 Published: 12 March 2014

\section{References}

1. Bushati N, Cohen SM: microRNA functions. Annu Rev Cell Dev Biol 2007, 23:175-205.

2. Bartel DP: MicroRNAs: genomics, biogenesis, mechanism, and function. Cell 2004, 116:281-297.

3. Pfeffer S, Zavolan M, Grasser FA, Chien M, Russo JJ, Ju J, John B, Enright AJ, Marks D, Sander C, Tuschl T: Identification of virus-encoded microRNAs. Science 2004, 304:734-736.

4. Pfeffer S, Sewer A, Lagos-Quintana M, Sheridan R, Sander C, Grasser FA, van Dyk LF, Ho CK, Shuman S, Chien M, Russo JJ, Ju J, Randall G, Lindenbach BD, Rice CM, Simon V, Ho DD, Zavolan M, Tuschl T: Identification of microRNAs of the herpesvirus family. Nat Methods 2005, 2:269-276.

5. Umbach JL, Cullen BR: The role of RNAi and microRNAs in animal virus replication and antiviral immunity. Genes Dev 2009, 23:1151-1164.

6. Klase ZA, Sampey GC, Kashanchi F: Retrovirus infected cells contain viral microRNAs. Retrovirology 2013, 10:15.

7. Schopman NC, Willemsen M, Liu YP, Bradley T, van Kampen A, Baas F, Berkhout B, Haasnoot J: Deep sequencing of virus-infected cells reveals HIV-encoded small RNAs. Nucleic Acids Res 2011, 40:414-427.

8. Kincaid RP, Burke JM, Sullivan CS: RNA virus microRNA that mimics a B-cell oncomiR. Proc Natl Acad Sci U S A 2012, 109:3077-3082.

9. Hussain M, Torres S, Schnettler E, Funk A, Grundhoff A, Pijlman GP, Khromykh AA, Asgari S: West Nile virus encodes a microRNA-like small RNA in the $3^{\prime}$ untranslated region which up-regulates GATA4 mRNA and facilitates virus replication in mosquito cells. Nucleic Acids Res 2012, 40:2210-2223.

10. Hutvagner G, Zamore PD: A microRNA in a multiple-turnover RNAi enzyme complex. Science 2002, 297:2056-2060.

11. Martinez J, Patkaniowska A, Urlaub H, Luhrmann R, Tuschl T: Single-stranded antisense siRNAs guide target RNA cleavage in RNAi. Cell 2002, 110:563-574

12. Bartel DP: MicroRNAs: target recognition and regulatory functions. Cell 2009, 136:215-233.

13. Lytle JR, Yario TA, Steitz JA: Target mRNAs are repressed as efficiently by microRNA-binding sites in the $5^{\prime}$ UTR as in the $3^{\prime}$ UTR. Proc Natl Acad Sci U S A 2007, 104:9667-9672.

14. Tay Y, Zhang J, Thomson AM, Lim B, Rigoutsos I: MicroRNAs to Nanog, Oct4 and Sox2 coding regions modulate embryonic stem cell differentiation. Nature 2008, 455:1124-1128.

15. Place RF, Li LC, Pookot D, Noonan EJ, Dahiya R: MicroRNA-373 induces expression of genes with complementary promoter sequences. Proc Natl Acad Sci U S A 2008, 105:1608-1613.

16. Younger ST, Corey DR: Transcriptional gene silencing in mammalian cells by miRNA mimics that target gene promoters. Nucleic Acids Res 2011, 39:5682-5691

17. Huang V, Place RF, Portnoy V, Wang J, Qi Z, Jia Z, Yu A, Shuman M, Yu J, Li LC: Upregulation of Cyclin B1 by miRNA and its implications in cancer. Nucleic Acids Res 2012, 40:1695-1707.

18. Jopling CL, Yi M, Lancaster AM, Lemon SM, Sarnow P: Modulation of hepatitis C virus RNA abundance by a liver-specific MicroRNA. Science 2005, 309:1577-1581.

19. Lecellier CH, Dunoyer P, Arar K, Lehmann-Che J, Eyquem S, Himber C, Saib A, Voinnet O: A cellular microRNA mediates antiviral defense in human cells. Science 2005, 308:557-560. 
20. Huang J1, Wang F, Argyris E, Chen K, Liang Z, Tian H, Huang W, Squires K, Verlinghieri G, Zhang H: Cellular microRNAs contribute to HIV-1 latency in resting primary CD4+ T lymphocytes. Nat Med 2007, 13:1241.

21. Sullivan CS, Grundhoff AT, Tevethia S, Pipas JM, Ganem D: SV40-encoded microRNAs regulate viral gene expression and reduce susceptibility to cytotoxic T cells. Nature 2005, 435:682-686.

22. Choy EY, Siu KL, Kok KH, Lung RW, Tsang CM, To KF, Kwong DL, Tsao SW, Jin DY: An Epstein-Barr virus-encoded microRNA targets PUMA to promote host cell survival. J Exp Med 2008, 205:2551-2560.

23. Stern-Ginossar N, Elefant N, Zimmermann A, Wolf DG, Saleh N, Biton M, Horwitz E, Prokocimer Z, Prichard M, Hahn G, Goldman-Wohl D, Greenfield C, Yagel S, Hengel H, Altuvia Y, Margalit H, Mandelboim O: Host immune system gene targeting by a viral miRNA. Science 2007, 317:376-381.

24. Bennasser $Y$, Le SY, Yeung ML, Jeang KT: HIV-1 encoded candidate micro-RNAs and their cellular targets. Retrovirology 2004, 1:43.

25. Klase Z, Kale P, Winograd R, Gupta MV, Heydarian M, Berro R, McCaffrey T, Kashanchi F: HIV-1 TAR element is processed by Dicer to yield a viral micro-RNA involved in chromatin remodeling of the viral LTR. BMC MOI Biol 2007, 8:63.

26. Ouellet DL, Plante I, Landry P, Barat C, Janelle ME, Flamand L, Tremblay MJ, Provost $P$ : Identification of functional microRNAs released through asymmetrical processing of HIV-1 TAR element. Nucleic Acids Res 2008, 36:2353-2365

27. Klase Z, Winograd R, Davis J, Carpio L, Hildreth R, Heydarian M, Fu S, McCaffrey T, Meiri E, Ayash-Rashkovsky M, Gilad S, Bentwich Z, Kashanchi F: HIV-1 TAR miRNA protects against apoptosis by altering cellular gene expression. Retrovirology 2009, 6:18.

28. Omoto S, Ito M, Tsutsumi Y, Ichikawa Y, Okuyama H, Brisibe EA, Saksena NK, Fujii YR: HIV-1 nef suppression by virally encoded microRNA. Retrovirology 2004, 1:44.

29. Yeung ML, Bennasser $Y$, Watashi K, Le SY, Houzet L, Jeang KT: Pyrosequencing of small non-coding RNAs in HIV-1 infected cells: evidence for the processing of a viral-cellular double-stranded RNA hybrid. Nucleic Acids Res 2009, 37:6575-6586.

30. Ouellet DL, Vigneault-Edwards J, Letourneau K, Gobeil LA, Plante I, Burnett JC, Rossi JJ, Provost P: Regulation of host gene expression by HIV-1 TAR microRNAs. Retrovirology 2013, 10:86.

31. Watts JM, Dang KK, Gorelick RJ, Leonard CW, Bess JW Jr, Swanstrom R, Burch $\mathrm{CL}$, Weeks KM: Architecture and secondary structure of an entire HIV-1 RNA genome. Nature 2009, 460:711-716.

32. Lin J, Cullen BR: Analysis of the interaction of primate retroviruses with the human RNA interference machinery. J Virol 2007, 81:12218-12226.

33. Zhang H, Zhou Y, Alcock C, Kiefer T, Monie D, Siliciano J, Li Q, Pham P, Cofrancesco J, Persaud D, Siliciano RF: Novel single-cell-level phenotypic assay for residual drug susceptibility and reduced replication capacity of drug-resistant human immunodeficiency virus type 1. J Virol 2004, 78:1718-1729.

34. Wei X, Decker JM, Liu H, Zhang Z, Arani RB, Kilby JM, Saag MS, Wu X, Shaw GM, Kappes JC: Emergence of resistant human immunodeficiency virus type 1 in patients receiving fusion inhibitor (T-20) monotherapy. Antimicrob Agents Chemother 2002, 46:1896-1905.

35. Purcell DF, Martin MA: Alternative splicing of human immunodeficiency virus type 1 mRNA modulates viral protein expression, replication, and infectivity. J Virol 1993, 67:6365-6378.

36. van Opijnen T, Kamoschinski J, Jeeninga RE, Berkhout B: The human immunodeficiency virus type 1 promoter contains a CATA box instead of a TATA box for optimal transcription and replication. J Virol 2004, 78:6883-6890

37. Morris KV, Chan SW, Jacobsen SE, Looney DJ: Small interfering RNA-induced transcriptional gene silencing in human cells. Science 2004, 305:1289-1292.

38. Li LC, Okino ST, Zhao H, Pookot D, Place RF, Urakami S, Enokida H, Dahiya R: Small dsRNAs induce transcriptional activation in human cells. Proc Natl Acad Sci U S A 2006, 103:17337-17342.

39. Janowski BA, Younger ST, Hardy DB, Ram R, Huffman KE, Corey DR: Activating gene expression in mammalian cells with promoter-targeted duplex RNAs. Nat Chem Biol 2007, 3:166-173.

40. Jones KA, Kadonaga JT, Luciw PA, Tjian R: Activation of the AIDS retrovirus promoter by the cellular transcription factor, Sp1. Science 1986, 232:755-759.
41. Harrich D, Garcia J, Wu F, Mitsuyasu R, Gonazalez J, Gaynor R: Role of SP1-binding domains in in vivo transcriptional regulation of the human immunodeficiency virus type 1 long terminal repeat. J Virol 1989, 63:2585-2591.

42. Rohr O, Sawaya BE, Lecestre D, Aunis D, Schaeffer E: Dopamine stimulates expression of the human immunodeficiency virus type 1 via NF-kappaB in cells of the immune system. Nucleic Acids Res 1999, 27:3291-3299.

43. Jacque JM, Fernandez B, Arenzana-Seisdedos F, Thomas D, Baleux F, Virelizier JL, Bachelerie F: Permanent occupancy of the human immunodeficiency virus type 1 enhancer by NF-kappa B is needed for persistent viral replication in monocytes. J Virol 1996, 70:2930-2938.

44. Cron RQ, Bartz SR, Clausell A, Bort SJ, Klebanoff SJ, Lewis DB: NFAT1 enhances HIV-1 gene expression in primary human CD4 T cells. Clin Immunol 2000, 94:179-191.

45. Robichaud GA, Barbeau B, Fortin JF, Rothstein DM, Tremblay MJ: Nuclear factor of activated $T$ cells is a driving force for preferential productive HIV-1 infection of CD45RO-expressing CD4+ T cells. J Biol Chem 2002, 277:23733-23741.

46. Sheridan PL, Sheline CT, Cannon K, Voz ML, Pazin MJ, Kadonaga JT, Jones KA Activation of the HIV-1 enhancer by the LEF-1 HMG protein on nucleosome-assembled DNA in vitro. Genes Dev 1995, 9:2090-2104.

47. Henderson AJ, Connor RI, Calame KL: C/EBP activators are required for HIV-1 replication and proviral induction in monocytic cell lines. Immunity 1996, 5:91-101.

48. Henderson AJ, Calame KL: CCAAT/enhancer binding protein (C/EBP) sites are required for HIV-1 replication in primary macrophages but not CD4 (+) T cells. Proc Natl Acad Sci U S A 1997, 94:8714-8719.

49. Rabbi MF, Saifuddin M, Gu DS, Kagnoff MF, Roebuck KA: U5 region of the human immunodeficiency virus type 1 long terminal repeat contains TRE-like cAMP-responsive elements that bind both AP-1 and CREB/ATF proteins. Virology 1997, 233:235-245.

50. Kato H, Horikoshi M, Roeder RG: Repression of HIV-1 transcription by a cellular protein. Science 1991, 251:1476-1479.

51. Yoon JB, Li G, Roeder RG: Characterization of a family of related cellular transcription factors which can modulate human immunodeficiency virus type 1 transcription in vitro. Mol Cell Biol 1994, 14:1776-1785.

52. Margolis DM, Somasundaran M, Green MR: Human transcription factor YY1 represses human immunodeficiency virus type 1 transcription and virion production. J Virol 1994, 68:905-910.

53. Subler MA, Martin DW, Deb S: Inhibition of viral and cellular promoters by human wild-type p53. J Virol 1992, 66:4757-4762.

54. Duan L, Ozaki I, Oakes JW, Taylor JP, Khalili K, Pomerantz RJ: The tumor suppressor protein p53 strongly alters human immunodeficiency virus type 1 replication. J Virol 1994, 68:4302-4313.

55. Rohr O, Marban C, Aunis D, Schaeffer E: Regulation of HIV-1 gene transcription: from lymphocytes to microglial cells. J Leukoc Biol 2003, 74:736-749.

56. Berkhout B, Silverman RH, Jeang KT: Tat trans-activates the human immunodeficiency virus through a nascent RNA target. Cell 1989, 59:273-282.

57. Brigati C, Giacca M, Noonan DM, Albini A: HIV Tat, its TARgets and the control of viral gene expression. FEMS Microbiol Lett 2003, 220:57-65.

58. Marzio G, Tyagi M, Gutierrez MI, Giacca M: HIV-1 tat transactivator recruits p300 and CREB-binding protein histone acetyltransferases to the viral promoter. Proc Natl Acad Sci U S A 1998, 95:13519-13524.

59. Mancebo HS, Lee G, Flygare J, Tomassini J, Luu P, Zhu Y, Peng J, Blau C, Hazuda D, Price D, Flores O: P-TEFb kinase is required for HIV Tat transcriptional activation in vivo and in vitro. Genes Dev 1997, 11:2633-2644.

60. Zhu Y, Pe'ery T, Peng J, Ramanathan Y, Marshall N, Marshall T, Amendt B, Mathews MB, Price DH: Transcription elongation factor P-TEFb is required for HIV-1 tat transactivation in vitro. Genes Dev 1997, 11:2622-2632.

61. Jowett JB, Planelles V, Poon B, Shah NP, Chen ML, Chen IS: The human immunodeficiency virus type $1 \mathrm{vpr}$ gene arrests infected $T$ cells in the G2 + M phase of the cell cycle. J Virol 1995, 69:6304-6313.

62. Hrimech M, Yao XJ, Bachand F, Rougeau N, Cohen EA: Human immunodeficiency virus type 1 (HIV-1) Vpr functions as an immediate-early protein during HIV-1 infection. J Virol 1999, 73:4101-4109.

63. Varin A, Manna SK, Quivy V, Decrion AZ, Van Lint C, Herbein G, Aggarwal BB: Exogenous Nef protein activates NF-kappa B, AP-1, and c-Jun N-terminal kinase and stimulates HIV transcription in promonocytic cells. Role in AIDS pathogenesis. J Biol Chem 2003, 278:2219-2227. 
64. Manninen A, Renkema GH, Saksela K: Synergistic activation of NFAT by HIV-1 nef and the Ras/MAPK pathway. J Biol Chem 2000, 275:16513-16517.

65. Chun TW, Engel D, Mizell SB, Hallahan CW, Fischette M, Park S, Davey RT Jr Dybul M, Kovacs JA, Metcalf JA, Mican JM, Berrey MM, Corey L, Lane HC,

Fauci AS: Effect of interleukin-2 on the pool of latently infected, resting CD4+ T cells in HIV-1-infected patients receiving highly active anti-retroviral therapy. Nat Med 1999, 5:651-655.

66. Prins JM, Jurriaans $S$, van Praag RM, Blaak $H$, van Rij R, Schellekens PT, ten Berge IJ, Yong SL, Fox CH, Roos MT, de Wolf F, Goudsmit J, Schuitemaker H, Lange JM: Immuno-activation with anti-CD3 and recombinant human IL-2 in HIV-1-infected patients on potent antiretroviral therapy. AIDS 1999, 13:2405-2410.

67. Kulkosky J, Culnan DM, Roman J, Dornadula G, Schnell M, Boyd MR, Pomerantz RJ: Prostratin: activation of latent HIV-1 expression suggests a potential inductive adjuvant therapy for HAART. Blood 2001, 98:3006-3015.

68. Ylisastigui L, Archin NM, Lehrman G, Bosch RJ, Margolis DM: Coaxing HIV-1 from resting CD4 T cells: histone deacetylase inhibition allows latent viral expression. AIDS 2004, 18:1101-1108.

69. Archin NM, Espeseth A, Parker D, Cheema M, Hazuda D, Margolis DM: Expression of latent HIV induced by the potent HDAC inhibitor suberoylanilide hydroxamic acid. AIDS Res Hum Retroviruses 2009, 25:207-212.

70. Contreras X, Schweneker M, Chen CS, McCune JM, Deeks SG, Martin J, Peterlin BM: Suberoylanilide hydroxamic acid reactivates HIV from latently infected cells. J Biol Chem 2009, 284:6782-6789.

71. Zuker M: Mfold web server for nucleic acid folding and hybridization prediction. Nucleic Acids Res 2003, 31:3406-3415.

72. Vermeire J, Naessens E, Vanderstraeten H, Landi A, lannucci V, Van Nuffel A, Taghon T, Pizzato M, Verhasselt B: Quantification of reverse transcriptase activity by real-time PCR as a fast and accurate method for titration of HIV, lenti- and retroviral vectors. PLoS One 2012, 7:e50859.

73. Dornadula G, Zhang H, VanUitert B, Stern J, Livornese L Jr, Ingerman MJ, Witek J, Kedanis RJ, Natkin J, DeSimone J, Pomerantz RJ: Residual HIV-1 RNA in blood plasma of patients taking suppressive highly active antiretroviral therapy. JAMA 1999, 282:1627-1632.

74. Yang S, Sun Y, Zhang H: The multimerization of human immunodeficiency virus type I Vif protein: a requirement for Vif function in the viral life cycle. J Biol Chem 2001, 276:4889-4893.

75. Gilman M: Ribonuclease protection assay. Curr Protoc Mol Biol 2001 Chapter 4:Unit4 7. http://www.ncbi.nlm.nih.gov/pubmed/18265241.

\section{doi:10.1186/1742-4690-11-23}

Cite this article as: Zhang et al: A novel HIV-1-encoded microRNA enhances its viral replication by targeting the TATA box region. Retrovirology 2014 11:23.

\section{Submit your next manuscript to BioMed Central and take full advantage of:}

- Convenient online submission

- Thorough peer review

- No space constraints or color figure charges

- Immediate publication on acceptance

- Inclusion in PubMed, CAS, Scopus and Google Scholar

- Research which is freely available for redistribution 